\title{
Serological Evidence for the Presence of Prunus Necrotic Ring Spot Virus in Stone Fruits with Particular Reference to Peach
}

\author{
Shelly Kapoor and Anil Handa* \\ Department of Biotechnology, Department of Plant Pathology, Dr. Y S Parmar University of \\ Horticulture and Forestry, Nauni- 173230, Solan, Himachal Pradesh, India \\ *Corresponding author
}

\section{A B S T R A C T}

Keywords

Prunus necrotic ring spot virus, DAS-ELISA, Stone fruits.

Article Info

Accepted: 29 June 2017 Available Online: 10 July 2017
Peach (Prunus persica) cv. July Elberta plants were surveyed from april to august in 2016 at various locations of major peach growing districts (Solan, Shimla and Sirmour) of Himachal Pradesh for the presence of Prunus Necrotic Ring Spot Virus (PNRSV) on the basis of symptoms exhibited by leaves and fruit prior to harvesting. Based on visual symptoms, percentage of incidence was found to range between 1-18 percent. PNRSV, being a latent virus cannot be assessed by symptoms alone. Thus, DAS-ELISA proved to be a quick and reliable method to confirm the presence of the virus. Cherry, Plum and Apricot were also indexed serologically to establish the host range of PNRSV.

\section{Introduction}

Peach (Prunus persica L. Batch) is one of the most popular and widely grown stone fruits throughout the world. It is native to northwest china and belongs to the family Rosaceae and genus Prunus which also includes Cherry and Plum. It is one of the most important fruit crops for the growers of Solan, Sirmour, Mandi, Kullu Shimla and Kangra districts of the Himachal Pradesh (Anonymous, 2016).

In India, peach is grown over an area of 18,000 hectares with an annual production of 94,000 metric tonnes. Jammu \& Kashmir, Uttar Pradesh, Punjab and Himachal Pradesh are the major peach producing states of India. In India, an area of 62,000 hectares is covered under peach with a total annual production of
123000 MT (Anonymous, 2016) whereas, in Himachal Pradesh total area under peach cultivation is 5076 hectare with a total production of 8045 MT (Anonymous, 2017). Among different cultivars of peach, July Elberta is the most widely cultivated cultivar in mid hills of Himachal Pradesh.

Peach is susceptible to many plant pathogens like fungi, bacteria and viruses. The most prominent virus infecting Peach, Prunus necrotic ring spot virus was suspected to be associated with peach in mid hill zone of Himachal Pradesh. During routine surveys conducted for recording the viral diseases in peach crop grown in and around Solan, Shimla and Sirmour districts, diseased plants 
exhibiting typical leaf distortion, brown lines with rings symptoms and diffused chlorotic spots leading to mottling on peach leaves were observed on a number of trees at many locations. Preliminary observations revealed the disease to be of viral etiology and resembling prunus necrotic ring spot symptoms often reported in rose and cherry from this part of the country.

The virus is transmitted naturally by grafting (Brunt et al., 1996; Fulton, 1970; Hammond, 2011), via seeds and pollen in several natural hosts, including Prunus spp, hops and roses and in some experimental hosts like Cucurbita maxima (Card et al., 2007; Hammond, 2011) Natural host range of the virus includes Prunus cerasus, Prunus persica, Rosa, Prunus domestica (plum), prunus dulcis (almond), Humulus (hops), Cucumis sativus (Brunt et al., 1996). Instance of natural infection of Rubus ellipticus (Yellow Himalyan Raspberry) by PNRSV has also been reported in India (Sharma et al., 1998).

\section{Surveys for the presence of PNRSV}

Different locations were selected in the main peach growing districts of Himachal Pradesh Viz., Solan, Shimla, Kullu and Sirmour. Sirmour referred to as the "Peach Valley" was surveyed for different orchards located at Pabyana, Haban, Kotli, Ratoli, Gauda, Sanaura, Bhanat and Fagu in district Sirmour; Nauni and Deothi, in district Solan; Mashobra, Phagli and Dhanda in district Shimla and at Bajaura, Seobagh and Manali in district Kullu.

Trees were surveyed from spring to autumn season to record the incidence of disease and on the basis of symptoms on leaves, the plants were marked as positive or negative. Positively marked trees were further indexed by DAS-ELISA to confirm the presence of
PNRSV. Percent disease incidence was calculated by using the following equation:

Number of diseased plants

Percent disease incidence $=$------------ X 100

Total number of plants observed

\section{DAS-ELISA}

Infected leaves showing symptoms of necrotic rings and distortion of mid vein collected from random branches of a single tree were considered as one composite sample and brought to the laboratory in ice bucket for conducting DAS-ELISA tests as per the protocol given by Clark and Adams (1977). Wells of the microtitre plate (BIOREBA, Switzerland certified microplates) except those of the top and bottom rows and rows on the extreme left and right, were filled with $200 \mu 1$ aliquots of coating antibodies diluted in $1 \mathrm{x}$ coating buffer $(1: 1000$ ratio $\mathrm{v} / \mathrm{v})$. The plate was incubated in humid box for 4 hours at $30^{\circ}$ C. The coating antibody suspension was removed by shaking out the plate over the wash basin. The wells were filled with $1 \mathrm{x}$ PBS-Tween and kept for 2 minutes with gentle shaking. The plate was emptied and filled again with PBS-Tween. The washing was repeated three times.

The test samples were grounded in $1 \mathrm{x}$ extraction buffer $(1: 10$ ratio $\mathrm{v} / \mathrm{v})$. All coated wells were filled with $200 \mu 1$ aliquots of test samples (each sample in duplicate) besides positive and negative control wells. The plate was incubated in humid box overnight at $4 \pm 1^{\circ}$ C. The washing steps were repeated as mentioned above. Alkaline phosphate (ALP) conjugated antibodies were filled in each well with $200 \mu 1$ aliquots after diluting it in 1x ECI (enzyme conjugated immunoglobin) buffer at a (ratio of 1:1000 v/v). The plate was incubated in humid box for 5 hours at $30^{\circ} \mathrm{C}$. The washing was done as mentioned above. p-nitrophenyl phosphate (pNPP) substrate was dissolved in $1 \mathrm{x}$ substrate buffer by 
dissolving $5 \mathrm{mg}$ pNPP tablet in $5 \mathrm{ml}$ of $1 \mathrm{x}$ substrate buffer. Each well was filled with $200 \mu 1$ aliquots of the substrate. The plate was kept in humid box in the dark condition at room temperature until a yellow colour was clearly visible in the positive control (usually between 30-60 minutes). The results were assessed either by visual observations or by measurement of the absorbance value of the hydrolysed substrate (p-nitrophenyl) at 405 $\mathrm{nm}$ wavelength in a microtitre plate reader (Micro Scan MS 5605A, Electronics Corporation of India Limited, Hyderabad). The results of ELISA for the detection were interpreted as per Dijkstra and Jager (1998) as samples were considered infected when their absorbance values $\left(\mathrm{A}_{405 \mathrm{~nm}}\right)$ exceeded two times the mean values of respective healthy control samples.

\section{Host range}

Different fruits belonging to stone fruits (Cherry, Plum and Apricot) were tested for the host range studies for PNRSV. Trees were indexed visually and samples from infected plants were brought to the laboratory for DAS-ELISA tests. Procedure of DAS-ELISA remained the same as for peach samples.

Fig.1 Cherry leaf showing diffused necrotic rings caused by PNRSV

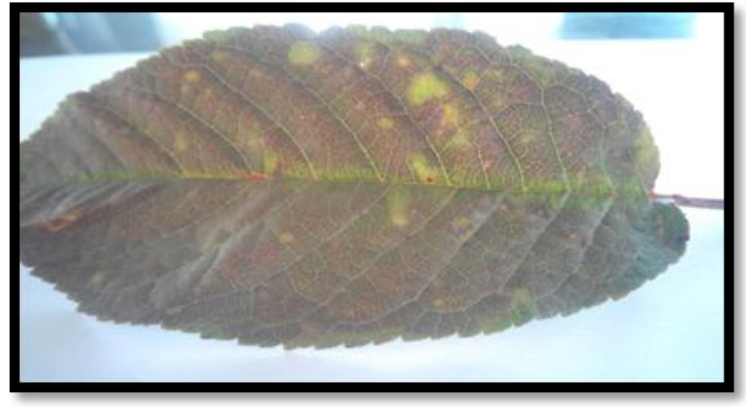

Fig.2 Symptoms of PNRSV on peach leaves

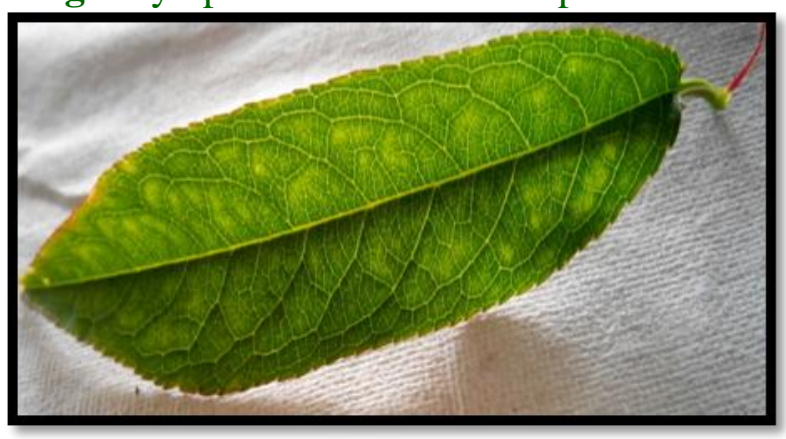

Fig.3 Symptoms of PNRSV on peach flowers

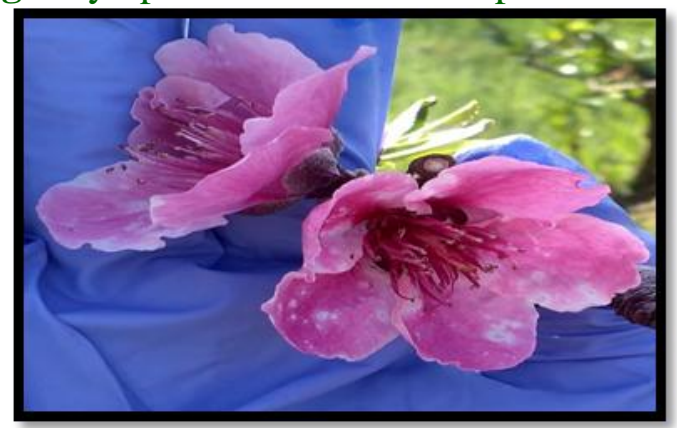


Table.1 Incidence of virus on peach trees in different orchards of major Peach growing districts of Himachal Pradesh

\begin{tabular}{|c|c|c|}
\hline Orchard No. & Location & Incidence (\%) \\
\hline Orchard-1 & Nauni, Solan & 13 \\
\hline Orchard-2 & Deothi, Solan & 15 \\
\hline Orchard-3 & Pabyana, Sirmaour & 11 \\
\hline Orchard-4 & Haban, Sirmaour & 10 \\
\hline Orchard-5 & Kotli, Sirmaour & 7 \\
\hline Orchard-6 & Ratoli, Sirmaour & 13 \\
\hline Orchard-7 & PCDO Gauda, Sirmaour & 17 \\
\hline Orchard-8 & Sanaura, Sirmaour & 11 \\
\hline Orchard-9 & Bhanat, Sirmaour & 10 \\
\hline Orchard-10 & Fagu, Sirmaour & 11 \\
\hline Orchard-11 & Shanna Ghat, Sirmaour & 17 \\
\hline Orchard-12 & Kwag Dhar, Sirmaour & 15 \\
\hline Orchard-13 & NBPGR Phagli, Shimla & 12 \\
\hline Orchard-14 & $\begin{array}{c}\text { IARI regional station } \\
\text { Dhanda, Shimla }\end{array}$ & 15 \\
\hline Orchard-15 & $\begin{array}{c}\text { IARI regional station } \\
\text { Bajaura, Kullu }\end{array}$ \\
\hline Orchard-16 & Seo Bagh, Kullu & 18 \\
\hline Orchard-17 & Manali, Kullu & \\
\hline
\end{tabular}

Table.2 Host range studies of PNRSV on stone fruits

\begin{tabular}{|c|c|c|c|c|c|}
\hline \multicolumn{2}{|c|}{ District and localities } & \multirow{2}{*}{$\begin{array}{l}\text { Antibody } \\
\text { PNRSV }\end{array}$} & \multicolumn{3}{|c|}{$\underline{\text { Mean O.D. value (A }} \underline{405} \underline{\mathrm{nm}})$} \\
\hline Solan & Host & & Present & Positive & Negative \\
\hline \multirow[t]{2}{*}{ Nauni } & Plum & & isolate & control & control \\
\hline & Apricot & & & & \\
\hline \multirow[t]{3}{*}{ Darlaghat } & Plum var. & & $0.262(+)$ & $0.210(+)$ & $0.067(-)$ \\
\hline & Myrobalan & & $0.234(+)$ & & \\
\hline & Pixy & & $0.258(+)$ & $0.286(+)$ & $0.072(-)$ \\
\hline \multicolumn{2}{|l|}{ Shimla } & & $0.283(+)$ & & \\
\hline \multirow[t]{2}{*}{ Mashobra } & Cherry & & $0.398(+)$ & $0.292(+)$ & $0.069(-)$ \\
\hline & Plum & & $0.338(+)$ & & \\
\hline \multirow{3}{*}{$\begin{array}{l}\text { Rampur } \\
\text { (Duttnagar) }\end{array}$} & Cherry var. & & $0.294(+)$ & $0.239(+)$ & $0.067(-)$ \\
\hline & Glory (Gisella-5) & & $0.286(+)$ & & \\
\hline & Regina(Gisell-5) & & & & \\
\hline
\end{tabular}


Table.3 Detection of PNRSV in different plant parts during Different time of the year by using DAS-ELISA

\begin{tabular}{|c|c|c|c|c|c|c|c|c|c|c|c|c|}
\hline \multirow{3}{*}{ Plant parts } & \multicolumn{12}{|c|}{ Mean OD values $\left(A_{405} \mathrm{~nm}\right) /($ Serological Reaction) } \\
\hline & \multicolumn{12}{|c|}{ Months } \\
\hline & Jan & Feb & Mar & Apr & May & June & July & Aug & Sept & Oct & Nov & Dec \\
\hline Leaves & & 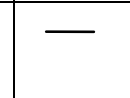 & - & $\begin{array}{l}0.340 \\
(+)\end{array}$ & $\begin{array}{l}0.293 \\
(+)\end{array}$ & $\begin{array}{c}0.269 \\
(+)\end{array}$ & $\begin{array}{l}0.256 \\
(+)\end{array}$ & $\begin{array}{l}0.203 \\
(-)\end{array}$ & - & - & - & - \\
\hline Bark & $\begin{array}{l}0.201 \\
(-)\end{array}$ & $\begin{array}{l}0.237 \\
(-)\end{array}$ & - & - & - & - & - & - & - & $\begin{array}{c}0.304 \\
(+)\end{array}$ & $\begin{array}{l}0.289 \\
(+)\end{array}$ & $\begin{array}{l}0.299 \\
(-)\end{array}$ \\
\hline Petals & & & $\begin{array}{c}0.859 \\
(+)\end{array}$ & - & - & - & 一 & - & - & - & - & - \\
\hline Fruits & - & 一 & 一 & $\ldots$ & - & $\begin{array}{l}0.199 \\
(-)\end{array}$ & - & 一 & - & - & - & \\
\hline +ve & 0.254 & 0.276 & 0.272 & 0.283 & 0.263 & 0.231 & 0.250 & 0.268 & 0.287 & 0.271 & 0.287 & 0.235 \\
\hline -ve & 0.068 & 0.074 & $\mid 0.134$ & 0.063 & 0.069 & 0.084 & 0.087 & 0.068 & 0.086 & 0.094 & 0.087 & 0.091 \\
\hline $\begin{array}{l}(+) \\
\text { (+ve) }\end{array}$ & & $\begin{array}{l}\text { Positive R } \\
\text { Positive c }\end{array}$ & $\begin{array}{l}\text { Reaction; } \\
\text { ontrol; }\end{array}$ & & & & gative re & $\begin{array}{l}\text { action; } \\
\text { ntrol }\end{array}$ & & & & \\
\hline
\end{tabular}

\section{Survey results and symptomatology}

In the present study, Prunus necrotic ring spot virus infecting peach and other stone fruits in Himachal Pradesh was investigated. The incidence of virus disease(s) in Peach grown at different locations ranged from 1-18 percent during the period of survey (Table 1). Maximum disease incidence of 18 percent was recorded at Manali in district Kullu followed by 17 percent at Gauda in district Sirmour. However, the least disease incidence of 7 percent was recorded at Kotli in district Sirmour.

\section{Host range studies}

Cherry, Plum and Apricot were also tested for establishing the host range of PNRSV. DASELISA results depicted positively reaction in isolates taken from different localities (Table 2). Cherry (Fig. 1) recorded the maximum presence of PNRSV based on the O.D. values recorded at $405 \mathrm{~nm}$ whereas apricot had the minimum concentration of the virus. The results are in conjunction with (Brunt et al., 1996) who reported these stone fruits to be the hosts of PNRSV. Similar results have also been reported by a number of workers (Salam et al., 2007; Myrtra et al., 2003; Gospodaryk et al., 2013) who reported the presence of PNRSV at high concentration in different stone fruits.

DAS-ELISA results for Peach cv. July Elberta

Positively marked trees on the basis of visual indexing were screened by DAS-ELISA from April to September for the presence of PNRSV. The virus was found in higher concentrations in leaves during April as young leaves had very low content of polyphenols. However, as the leaves mature the polyphenols content increased resulting in no symptom and decline in virus concentration (Fig. 2). Similar results have been reported by Salem et al., (2003) and Myrtra et al., (2001) who reported the occurence of PNRSV possibly resulting from in Peach using DAS-ELISA. Ripe fruits were also tested but showed no presence of PNRSV possibly resulting from a passage breakdown of virus to fruits due to the lack of plasmodesmetal connections. It was also found that the fruit size decreased in diseased trees when compared to healthy trees which could be the possible reason for the reduced yield as mentioned by Pusey et 
al., (1991). Bark tissues of positively tested trees were used for DAS-ELISA from October to February till fresh flush of leaves appears. The results confirmed the presence of PNRSV in bark tissues from October to December in high concentration, since the virus is graft transmissible in nature, there is every possibility of the virus to be prevalent in the bark. Peach flowers were also tested for the presence of PNRSV in the month of March and the results revealed a high concentration of PNRSV in petals (Fig. 3). Since, petals have high sap content with negligible polyphenols, they may have high concentration of the virus. The overall concentration of the virus was recorded in different plant parts of peach plant throughout the year (Table 3).

\section{References}

Anonymous, 2016, http://nhb.gov.in

Anonymous, 2017, www. hpagrisnet.gov.in/horticulture

Brunt, A.A., Crabtree, K., Dallwitz, M.J., Gibbs. A.J. and Watson, L. (eds.) 1996. Viruses of plants: Description and list from the VIDE Database. University Press, Cambridge. 1484 pp.

Card, S.D., Pearson, M.N. and Clover, G.R.G. 2007. Plant pathogens transmitted by pollens. Aust. Plant Pathol., 36: 455-461.

Clark, M.F. and Adams A.N. 1977. Characteristics of microplate method enzyme linked immunosorbent assay for the detection of plant viruses. J. Gen. Virol., 34: 475-483.

Dijksha, J., and Jager, C.D. 1998. Practical Plant Virology. Springer Lab Manuals. $145 \mathrm{pp}$.

Fulton, $\quad$ R. W. http://Biology.
anu.edu.au/groups/MES/Vide.

Hammond, R.W., 2011. Prunus necrotic ring spot virus. In virus and virus-like diseases of pome and stone fruits (eds.) Hadidi, A., Barbra, M., Candresse, T. and Jelkmann, W. APS press, St Paul, MN, USA. 207213pp.

Gospodaryk, A., Bicevska, I.M., Pupola, N. and Kale, A. 2013. Occurrence of stone fruit viruses in Plum orchards in Latvia. Proc. Latvian Acad. Sci., 67:116-123.

Myrta, A., Terlizzi, B.D., Boscia, D., Choueiri, E., Gatt, M., Gawriel, I., Caglayan, K., Varveri, C., Zerandini, H., Aparici, F., Pallas, V. and Savino, V. 2001. Serological characterization of Mediterranean PNRSV isolates. J. Plant Pathol., 83:45-49.

Myrtra, A., Terlizzi, B.D., Savino, V. and Martelli, G. P. 2003. Virus diseases affecting the Mediterranean stone fruit Industry: A decade of surveys. CIHEAM. 15-23pp.

Pusey, P.L., 1991. Influence of Prunus Necrotic Ring Spot Virus on Growth, Productivity and Longevity of Peach trees. Plant Dis., 65: 847-851.

Sharma, A., Ram, R. and Zaidi, A.A. 1998. Rubus ellipticus, a perennial weed host of Prunus necrotic ring spot virus in India. Plant Dis., 82:1283-1294.

Salam, A.M., Ibrahim, A.M., Abdelkader, S.H., Aly, A.M.E. and Saghir, S.M.E. 2007. Characterization of two isolates of PNRSV from peach and apricot in Egypt. Arab J. Biotechnol., 11: 107-124.

Salem, N., Mansour, A., Musa, A.A. and Nsour, A.A. 2003. Incidence of PNRSV in Jordan. Phytoplatholgy. Mediterenian 42: 275-279.

\section{How to cite this article:}

Shelly Kapoor and Anil Handa. 2017. Serological Evidence for the Presence of Prunus Necrotic Ring Spot Virus in Stone Fruits with Particular Reference to Peach. Int.J.Curr.Microbiol.App.Sci. 6(7): 4078-4083. doi: https://doi.org/10.20546/ijcmas.2017.607.423 